\title{
Aphrodisiac properties of Aquilaria malaccensis leaves aqueous extract in ICR mice
}

\author{
Nur Hidayat CHE MUSA ${ }^{1}$, Haniza Hanim MOHD ZAIN ${ }^{1}{ }^{*}$, Husni IBRAHIM ${ }^{1}$ \\ 1 Department of Biology, Faculty of Science and Mathematics, Universiti Pendidikan Sultan Idris (UPSI), \\ 35900, Tanjong Malim, Perak, Malaysia. \\ * Corresponding Author. E-mail: haniza@fsmt.upsi.edu.my (N.H.C.M.); Tel. +6015-48797204; ORCID No: 0000-0002- \\ $7627-4046$
}

Received: 22 February 2018 / Revised: 23 May 2018 / Accepted: 24 May 2018

\begin{abstract}
The study was conducted to investigate the effects of Aquilaria malaccensis leaves aqueous extracts on the aphrodisiac properties, which included; sexual behaviour, orientation activity, and testosterone level in ICR mice. Thirty healthy and sexually experienced male and thirty non-estrous female mice were used. In this experiment, each male was cohabitated with one female in a polysulfone cage. The mice were divided into 6 groups that received normal saline (control group), $50 \mathrm{mg} / \mathrm{kg}, 100 \mathrm{mg} / \mathrm{kg}$, $200 \mathrm{mg} / \mathrm{kg}, 500 \mathrm{mg} / \mathrm{kg}$, and $1000 \mathrm{mg} / \mathrm{kg}$ body weight of A. malaccensis leaves aqueous extract orally for 21 days consecutively. Results showed that all aphrodisiac parameters investigated in this study were similar between the treatment groups to the control group. However, two treated groups that received 100 $\mathrm{mg} / \mathrm{kg}$ (day 14; day 21) and $200 \mathrm{mg} / \mathrm{kg}$ (day 0; day 21) resulted in significantly higher in mount frequency as compared to the control group. Overall, the results revealed that $A$. malaccensis leaves aqueous extract did not significantly alter the aphrodisiac parameters. Thus, this study validated that $A$. malaccensis leaves aqueous extracts lack of aphrodisiac properties in mice.
\end{abstract}

KEYWORDS: Aquilaria malaccensis; aphrodisiac; sexual behaviour; orientation activity; testosterone.

\section{INTRODUCTION}

Sexual dysfunction can be defined as the failure to accomplish a normal sexual intercourse comprising premature ejaculation, retrograded, retarded ejaculation, erectile dysfunction, arousal problems (reduced libido), compulsive sexual behaviour and orgasmic disorder [1,2]. It is common among men of any age, ethnicities, and cultural backgrounds. The most widely recognized issue in male sexual dysfunction is erectile dysfunction. Erectile dysfunction is described as the steady failure to accomplish an erection sufficient for the purpose of satisfactory sexual intercourse, or the inability to ejaculate, or both [3]. In some cases, the terms erectile dysfunction, infertility problems and sterility issues are used to describe the similar thing since it seems not easy to clearly distinguish using traditional ethnobotanical data [4].

Some major causes that might be contribute to this infertility problem also consist of psychological disturbances, i.e. performance anxiety, strained relationship, depression, stress, guilt and fear of sexual failure; neurological disorders such as Parkinson's disease, Alzhemier's disease, spinal cord or nerve injury; deficiencies in sex hormones; side effects associated with chronic use of drugs like anti-hypertensives, central agents, psychiatric medications, antiulcer, antidepressants, anti-androgens and lifestyle related problems, i.e. chronic alcohol abuse, drug abuse and cigarette smoking [5].

In developing countries like Malaysia, the inability to afford modern medical therapy for infertility problem has forced patients to seek for traditional plant medicine. Traditional plant medicine or also known as phytotherapy with aphrodisiac properties provides a safer way to counteract with various problems associated with male infertility [6]. The phytotherapy has become more popular among the community because it is being natural, cheap, having the fewer side effect, easy to access and good therapeutic outcome [7].

Some plant species have been investigated for their use as sex stimulants and fertility enhancing agent in traditional medicines including Eurycoma longifolia [8, 9], Ficus deltoidea [10], Nigella sativa [11], Lunasia amara [12], Gynura procumbens [13], and Chlorophytum borivilianum [14]. Another potential plant for aphrodisiac and

How to cite this article: Che Musa $\mathrm{NH}$, Mohd Zain $\mathrm{HH}$, Ibrahim $\mathrm{H}$. Aphrodisiac properties of Aquilaria malaccensis leaves aqueous extract in ICR mice. J Res Pharm. 2019; 23(1): 130-140. 
fertility purpose that still not investigate belongs to the genus of Aquilaria which is Aquilaria malaccensis. This species also known as agarwood and it is belonging to the family of Thymelaeaceae. Five main species of agarwood remained well distributed in Malaysia including A. malaccencis, A. hirta, A. beccariana, A. rostrata and A. microcarpa [15].

Agarwood leaves are frequently used in folk medicine in many countries for the promotion of good health and treatment of many ailments. A lot of studies have been done by previous researchers from various countries to verify this issues scientifically. Many previous studies have been performed on the effect of different species of the agarwood leaves extracts as the treatment of anticancer [16], Alzheimer's disease [17], therapeutic laxative agent [18, 19], antipyretic and anti-inflammatory [20], antimicrobial [21, 22], and antihyperglycemic activity [23].

The phytochemical constituents found by previous researchers in Aquilaria leaves extract are flavonoid glycosides [24], 2-(2-phenylethyl)chromenes [25], lignans [26] and diterpenoids [27]. Besides, the chemical constituents that consist of alkaloids, tannins, saponins, flavonoids, and terpenoids also are available in the Aquilaria leaves extract $[28,16]$. Traditionally, the utilization of agarwood as aphrodisiac agent already claimed by several previous studies [29-31]. There are some phytochemicals that possess to aphrodisiac properties which are saponins [3, 32], alkaloids [33] as well as flavonoids [34, 35] since these phytochemicals have androgen enhancing and antioxidant properties. Thus, the presence of various phytochemical constituents by previous researchers specifically saponins, alkaloids, and flavonoids as well as the subjective opinion that provided by local communities additionally become the backbone for the aphrodisiac investigation.

However, no studies have been reported till date on agarwood leaves extracts that may act as aphrodisiac agent in men scientifically although it has been used traditionally for years specifically in Malaysia. This study was therefore designed to investigate the effects of the aqueous extract of a species of agarwood; A. malaccensis on the sexual behaviour, orientation activity and testosterone estimation of ICR male mice to validate the use of the plant, mentioned as an aphrodisiac in the folklore medicine.

\section{RESULTS AND DISCUSSION}

The study was conducted to investigate the effects of Aquilaria malaccensis leaves aqueous extracts (AEAM) on the aphrodisiac properties, which included; sexual behaviour, orientation activity and testosterone level in ICR mice.

\subsection{Effect on sexual behaviour}

In the present study, the sexual behaviour parameters observed were mount frequency (MF), intromission frequency (IF), mount latency (ML) and intromission latency (IL). Despite the fact that ejaculation frequency was not performed in this study, both mount and intromission frequencies were already sufficient, which are valuable indices of vigour, libido, and potency [36]. Besides, it was exceptionally hard even for a skilled observer to distinguish between intromission and ejaculation in observation of sexual behaviour [37]. The effects of the various dose of crude extracts on sexual behaviour are summarized in Table 2. Among all the physical indices of sexual behaviour monitored in male mice, AEAM 100 (day 14; day 21) and AEAM 200 (day 0; day21) resulted in significantly higher in mount frequency as compared to the control group. Contrariwise, the other treatment groups showed significantly lower $(p<0.05)$ in mount frequency for all observation days except AEAM 200 (day 14) as compared to the control group (Figure 1).

However, mount and intromission latencies for the treatment groups remained similar to the control group. The dose-dependent increase in the time spent for the first mount and intromission being recorded among the treated groups compared to the control group. Nil values were recorded on intromission frequency and intromission latency in all groups because the mice being passive and sleepy starting from day 7 until the end of observation period (day 21) especially the treated mice groups that received the crude extract. Generally, mount and intromission latencies were used as indicators of sexual motivation [38]. However, they also claimed that ML and IL are inversely proportional to sexual motivation. In this way, the decrease in the mount and intromission latencies was the positive result for the extract which might imply stimulation of sexual motivation and arousability. It may also be the sign of boosted sexual appetitive behaviour in experimental animals which further supports the sexual improvement effect of the plant extract $[38,39]$. 


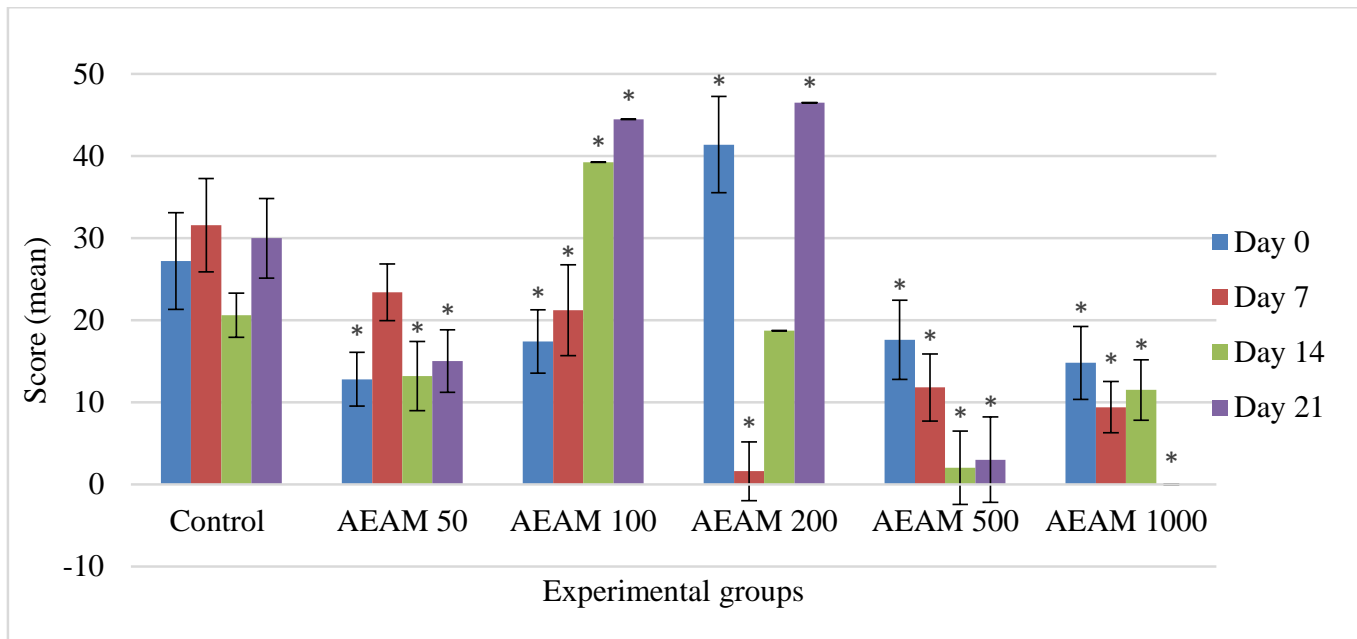

Note, *the mean difference is significant at $\mathrm{p}<0.05$

Figure 1. Various doses effect of A. malaccensis aqueous leaves extract in mean scoring of mount frequency towards mice.

Contrary results were obtained from the present study because AEAM was lack of aphrodisiac properties. Furthermore, the administration of AEAM in high dose caused sedative effect in terms of reducing sexual behaviour and orientation activity towards female and towards self. Additionally, the treated animals with AEAM also did not indicate enough attraction to the females but rather appeared to be tired or sleepy and were not ready to move towards the females. This agreed with the findings of [1] and [40] who observed sexual behaviour parameters with $100 \mathrm{mg} / \mathrm{kg}$ body weight of Bulbine natalensis stem and $200 \mathrm{mg} / \mathrm{kg}$ body weight of Massularia acuminata root respectively in male rats. This condition also resulted in reducing of MF and IF in the treated animals and this sedative effect obviously appeared after 30 minutes of observation period. Though, mount and intromission latencies for the treatment groups showed insignificantly different as compared to control group. Moreover, observation at each experimental period in this investigation found that the sexual function in treated mice was not enhanced, especially in a few parameters of sexual behaviour such as IF and IL which had no value (Table 2). A similar finding was reported on Garcinia kola seeds in male Wistar rats [41].

The higher values of mount and intromission latencies observed in AEAM treated mice is one of the main indicator of an increase in the hesitation time of the male mice towards the female mice [1,39]. This situation was demonstrated when the vast majority of the treated mice were not attracted to their opposite gender. Besides, the dissimilarity in the values of MF and IF were also being recorded in treated animals throughout the experimental period. This situation was supported by the previous study [39], they suggested that every number of mount recorded in treated animals was not determined the success of intromission (the phase that recognized when the copulatory organ enters the vagina during a mount).

\subsection{Effect on orientation activity}

Orientation activity parameters were observed from the polysulfone cage side when the extract treated male mice were introduced to the female mice. The effects of the various dose of AEAM on orientation behaviour are summarized in Table 3. The mean orientation score towards environment (rearing) showed significantly higher $(\mathrm{p}<0.05)$ in AEAM 200 on day 7 as compared to the control group. The orientation activity towards environment (climbing) revealed significantly higher $(\mathrm{p}<0.05$ ) in AEAM 50 (day 0), AEAM 100 (day 0), AEAM 200 (day 0) and AEAM 500 (day 21) than the control group. In contrast, AEAM 50, AEAM 100 and AEAM 200 on day 14 was found to have significantly lower $(p<0.05)$ in climbing than the control group. 
Table 2. Effect of Aquilaria malaccensis leaves aqueous extracts on mean scoring of sexual behaviour in male mice

\begin{tabular}{|c|c|c|c|c|}
\hline Group (am) & $\begin{array}{l}\text { Mount frequency } \\
(\text { mean } \pm S D)\end{array}$ & $\begin{array}{l}\text { Mount latency } \\
\text { (minutes) } \\
(\text { mean } \pm \text { SD) }\end{array}$ & $\begin{array}{l}\text { Intromission } \\
\text { frequency } \\
(\text { mean } \pm S D)\end{array}$ & $\begin{array}{l}\text { Intromission } \\
\text { latency (minutes) } \\
\text { (mean } \pm \mathrm{SD})\end{array}$ \\
\hline \multicolumn{5}{|l|}{ Control } \\
\hline Day 0 & $27.20 \pm 5.89$ & $2.09 \pm 1.81$ & $3.60 \pm 5.68$ & $19.95 \pm 13.30$ \\
\hline Day 7 & $31.60 \pm 5.68$ & $1.74 \pm 1.41$ & $0.20 \pm 0.45$ & $6.05 \pm 0.00$ \\
\hline Day 14 & $20.60 \pm 2.70$ & $4.67 \pm 4.44$ & $0.00 \pm 0.00$ & $0.00 \pm 0.00$ \\
\hline Day 21 & $30.00 \pm 4.85$ & $1.10 \pm 0.82$ & $0.00 \pm 0.00$ & $0.00 \pm 0.00$ \\
\hline \multicolumn{5}{|l|}{ AEAM 50} \\
\hline Day 0 & $12.80 \pm 3.27^{*}$ & $4.04 \pm 4.76$ & $0.00 \pm 0.00$ & $0.00 \pm 0.00$ \\
\hline Day 7 & $23.40 \pm 3.44$ & $7.01 \pm 10.73$ & $0.20 \pm 0.45$ & $67.21 \pm 0.00$ \\
\hline Day 14 & $13.20 \pm 4.21^{*}$ & $19.65 \pm 15.54$ & $0.00 \pm 0.00$ & $0.00 \pm 0.00$ \\
\hline Day 21 & $15.00 \pm 3.81^{*}$ & $9.33 \pm 15.18$ & $0.40 \pm 0.89$ & $48.23 \pm 0.00$ \\
\hline \multicolumn{5}{|l|}{ AEAM 100} \\
\hline Day 0 & $17.40 \pm 3.85^{*}$ & $5.36 \pm 6.22$ & $0.00 \pm 0.00$ & $0.00 \pm 0.00$ \\
\hline Day 7 & $21.20 \pm 5.54^{*}$ & $1.10 \pm 0.78$ & $0.00 \pm 0.00$ & $0.00 \pm 0.00$ \\
\hline Day 14 & $39.25 \pm 0.00^{*}$ & $1.93 \pm 2.42$ & $1.20 \pm 2.68$ & $60.54 \pm 0.00$ \\
\hline Day 21 & $44.50 \pm 0.00^{*}$ & $0.94 \pm 0.97$ & $0.20 \pm 0.45$ & $0.00 \pm 0.00$ \\
\hline \multicolumn{5}{|l|}{ AEAM 200} \\
\hline Day 0 & $41.40 \pm 5.86^{*}$ & $1.68 \pm 2.16$ & $0.80 \pm 1.10$ & $5.24 \pm 0.00$ \\
\hline Day 7 & $1.60 \pm 3.58^{*}$ & $25.19 \pm 0.00$ & $0.00 \pm 0.00$ & $0.00 \pm 0.00$ \\
\hline Day 14 & $18.75 \pm 0.00$ & $2.11 \pm 1.74$ & $0.75 \pm 0.96$ & $57.74 \pm 68.55$ \\
\hline Day 21 & $46.50 \pm 0.00^{*}$ & $1.65 \pm 1.12$ & $0.50 \pm 1.00$ & $98.20 \pm 0.00$ \\
\hline \multicolumn{5}{|l|}{ AEAM 500} \\
\hline Day 0 & $17.60 \pm 4.83^{*}$ & $3.70 \pm 4.34$ & $4.80 \pm 2.17$ & $26.23 \pm 0.00$ \\
\hline Day 7 & $11.80 \pm 4.09^{*}$ & $1.36 \pm 0.00$ & $0.00 \pm 0.00$ & $0.00 \pm 0.00$ \\
\hline Day 14 & $2.00 \pm 4.47^{*}$ & $14.09 \pm 0.00$ & $0.00 \pm 0.00$ & $0.00 \pm 0.00$ \\
\hline Day 21 & $3.00 \pm 5.20^{*}$ & $1.54 \pm 1.25$ & $0.00 \pm 0.00$ & $0.00 \pm 0.00$ \\
\hline \multicolumn{5}{|l|}{ AEAM 1000} \\
\hline Day 0 & $14.80 \pm 4.44^{*}$ & $3.11 \pm 2.57$ & $0.00 \pm 0.00$ & $0.00 \pm 0.00$ \\
\hline Day 7 & $9.40 \pm 3.13^{*}$ & $24.26 \pm 34.99$ & $0.00 \pm 0.00$ & $0.00 \pm 0.00$ \\
\hline Day 14 & $11.50 \pm 3.70^{*}$ & $5.37 \pm 6.15$ & $0.00 \pm 0.00$ & $0.00 \pm 0.00$ \\
\hline Day 21 & $0.00 \pm 0.00^{*}$ & $0.00 \pm 0.00$ & $0.00 \pm 0.00$ & $0.00 \pm 0.00$ \\
\hline
\end{tabular}

* The mean difference is significant at $\mathrm{p}<0.05$ level $\mathrm{n}=5$ in each group

Besides, the orientation towards female in all treated groups showed the reduction in sniffing as compared to the control group except AEAM 50 (day 0). The orientation towards female (licking) also caused significantly lower $(\mathrm{p}<0.05)$ for their mean of scoring in AEAM 50 (day7; day 14), AEAM 500 and AEAM 1000 as compared to the control group. However, highly significant $(p<0.05)$ of licking also being recorded for AEAM 50 and AEAM 100 on day 0 as compared to the control. The orientation towards self (genital grooming) was found to be gradually decreased along the addition of experimental period in all treated groups. But, among them AEAM 200 (day 7), AEAM 500 (day 7 and day 21) and AEAM 1000 (day 7 and day 21) showed the significantly lower $(\mathrm{p}<0.05)$ in genital grooming when compared to the control group.

During observation period, the male mice in all groups, upon introduction, reacted with immediate advances toward the females and displayed sexual interest towards female mice such as chasing, genital sniffing and licking which eventually ended into mounting and intromission. However, the prolong treatment with AEAM caused inconsistently decrease in orientation activity especially towards female and towards self that recorded in treated animals. In contrast, orientation activity which was exploration depicted to be higher in treated groups than control group specifically in AEAM 500 and 1000. This result is parallel with the finding from the previous study [41]. They reported that there were no sexual enhancing properties in the aqueous extract of Garcinia kola seeds in male Wistar rats. 
Table 3. Effect of $A$. malaccensis leaves aqueous extracts on mean scoring of orientation activities in male mice.

\begin{tabular}{|c|c|c|c|c|c|c|}
\hline \multirow[t]{3}{*}{ Group } & \multicolumn{6}{|c|}{ Activity score (mean \pm SD) } \\
\hline & \multicolumn{3}{|c|}{ Towards environment } & \multicolumn{2}{|c|}{ Towards female } & \multirow{2}{*}{$\begin{array}{l}\text { Towards } \\
\text { self } \\
\text { Genital } \\
\text { grooming }\end{array}$} \\
\hline & Exploration & Rearing & Climbing & Sniffing & Licking & \\
\hline \multicolumn{7}{|l|}{ Control } \\
\hline Day 0 & $4.60 \pm 1.67$ & $6.40 \pm 4.16$ & $17.00 \pm 5.10$ & $12.00 \pm 4.40$ & $11.00 \pm 1.87$ & $5.20 \pm 2.17$ \\
\hline Day 7 & $2.60 \pm 0.89$ & $6.40 \pm 5.59$ & $16.40 \pm 4.34$ & $9.80 \pm 5.81$ & $13.80 \pm 5.63$ & $4.80 \pm 1.64$ \\
\hline Day 14 & $2.60 \pm 0.89$ & $6.20 \pm 4.55$ & $24.40 \pm 3.21$ & $5.20 \pm 1.92$ & $13.00 \pm 4.85$ & $3.20 \pm 0.84$ \\
\hline Day 21 & $1.80 \pm 0.45$ & $5.20 \pm 3.42$ & $10.80 \pm 5.63$ & $2.80 \pm 0.84$ & $7.20 \pm 3.03$ & $5.20 \pm 1.30$ \\
\hline \multicolumn{7}{|c|}{ AEAM 50} \\
\hline Day 0 & $5.00 \pm 2.65$ & $6.40 \pm 3.29$ & $26.80 \pm 4.66^{*}$ & $27.80 \pm 5.50^{*}$ & $19.4 \pm 4.39^{*}$ & $5.40 \pm 1.14$ \\
\hline Day 7 & $1.40 \pm 0.55$ & $2.00 \pm 1.87$ & $8.20 \pm 4.21$ & $3.40 \pm 1.52$ & $5.40 \pm 4.51^{*}$ & $3.40 \pm 1.34$ \\
\hline Day 14 & $1.60 \pm 0.89$ & $5.40 \pm 3.21$ & $13.80 \pm 3.70^{*}$ & $2.40 \pm 1.95$ & $3.60 \pm 2.19^{*}$ & $3.20 \pm 1.64$ \\
\hline Day 21 & $2.20 \pm 1.10$ & $5.60 \pm 3.29$ & $12.20 \pm 3.35$ & $2.00 \pm 1.00$ & $3.60 \pm 0.89$ & $3.20 \pm 2.28$ \\
\hline \multicolumn{7}{|c|}{ AEAM 100} \\
\hline Day 0 & $5.00 \pm 1.22$ & $10.20 \pm 3.77$ & $32.40 \pm 3.21^{*}$ & $6.40 \pm 5.73$ & $10.20 \pm 3.27$ & $3.80 \pm 1.48$ \\
\hline Day 7 & $1.20 \pm 0.84$ & $2.20 \pm 1.48$ & $11.00 \pm 5.83$ & $3.00 \pm 1.00$ & $7.00 \pm 3.08$ & $3.20 \pm 1.10$ \\
\hline Day 14 & $1.60 \pm 0.55$ & $5.00 \pm 1.87$ & $15.00 \pm 5.79^{*}$ & $2.80 \pm 1.10$ & $8.00 \pm 4.42$ & $2.80 \pm 1.92$ \\
\hline Day 21 & $2.00 \pm 0.71$ & $2.80 \pm 2.28$ & $12.8 \pm 2.86$ & $2.60 \pm 1.52$ & $6.60 \pm 3.78$ & $3.60 \pm 2.88$ \\
\hline \multicolumn{7}{|c|}{ AEAM 200} \\
\hline Day 0 & $3.60 \pm 0.89$ & $7.40 \pm 5.32$ & $27.40 \pm 4.93^{*}$ & $15.00 \pm 4.64$ & $18.80 \pm 2.95^{*}$ & $3.60 \pm 1.14$ \\
\hline Day 7 & $3.80 \pm 5.26$ & $14.80 \pm 4.38^{*}$ & $26.6 \pm 4.67$ & $5.20 \pm 5.36$ & $6.80 \pm 3.03$ & $0.02 \pm 0.45^{*}$ \\
\hline Day 14 & $1.20 \pm 0.84$ & $6.00 \pm 5.16$ & $8.25 \pm 1.50$ * & $4.40 \pm 3.97$ & $7.60 \pm 3.58$ & $3.20 \pm 3.83$ \\
\hline Day 21 & $2.00 \pm 1.22$ & $11.25 \pm 2.87$ & $17.75 \pm 3.77$ & $3.60 \pm 1.95$ & $7.40 \pm 3.97$ & $3.80 \pm 2.86$ \\
\hline \multicolumn{7}{|c|}{ AEAM 500} \\
\hline Day 0 & $1.80 \pm 0.84$ & $1.60 \pm 0.55$ & $12.40 \pm 5.18$ & $3.80 \pm 2.39$ & $4.60 \pm 3.51^{*}$ & $4.20 \pm 3.77$ \\
\hline Day 7 & $3.40 \pm 1.95$ & $8.60 \pm 4.45$ & $18.20 \pm 4.38$ & $1.60 \pm 2.61^{*}$ & $3.60 \pm 1.34^{*}$ & $1.80 \pm 2.05^{*}$ \\
\hline Day 14 & $4.00 \pm 1.58$ & $6.40 \pm 4.22$ & $22.80 \pm 5.26$ & $1.80 \pm 1.30$ & $3.40 \pm 3.21^{*}$ & $1.40 \pm 0.55$ \\
\hline Day 21 & $2.20 \pm 1.30$ & $5.40 \pm 4.39$ & $19.00 \pm 4.18^{*}$ & $1.40 \pm 0.55$ & $2.20 \pm 1.92$ & $1.00 \pm 0.71^{*}$ \\
\hline \multicolumn{7}{|c|}{ AEAM 1000} \\
\hline Day 0 & $2.40 \pm 1.14$ & $1.20 \pm 0.84$ & $11.80 \pm 3.90$ & $2.20 \pm 1.10^{*}$ & $4.40 \pm 2.88^{*}$ & $2.00 \pm 0.71$ \\
\hline Day 7 & $2.80 \pm 2.17$ & $5.20 \pm 4.76$ & $16.80 \pm 7.40$ & $1.40 \pm 1.95^{*}$ & $2.40 \pm 3.36^{*}$ & $0.60 \pm 0.89^{*}$ \\
\hline Day 14 & $2.75 \pm 0.96$ & $5.00 \pm 2.94$ & $23.00 \pm 4.83$ & $1.75 \pm 0.96$ & $2.50 \pm 3.32^{*}$ & $1.50 \pm 1.00$ \\
\hline Day 21 & $2.50 \pm 1.29$ & $6.25 \pm 4.43$ & $14.75 \pm 3.59$ & $0.50 \pm 0.58$ & $0.75 \pm 1.50^{*}$ & $0.50 \pm 1.00^{*}$ \\
\hline
\end{tabular}

* The mean difference is significant at $\mathrm{p}<0.05$ level ( $\mathrm{n}=5$ in each group)

\subsection{Effect on testosterone level}

The effect of the oral administration of AEAM on testosterone level is presented in Table 4 . The extract showed no significant changes $(\mathrm{p}<0.05)$ in testosterone concentration at all doses administered when compared with the control. However, AEAM 200 showed slight increase and the other treated groups showed slight decrease in testosterone level as compared to the control. In general, elevated testosterone level also boosts the sexual behaviour in humans $[42,43]$. Therefore, an increase in testicular and serum free testosterone concentration will confirm aphrodisiac potential inherent in the plant extract. Commonly, high level of testosterone in the male reproductive system is closely related to the increase of Luteinizing hormone (LH) concentration and the presence of secondary phytochemical which capable to mimic the function of LH to stimulate interstitial cells in testosterone production [44]. 
Table 4. Effect of aqueous leaves extract of $A$. malaccensis on testosterone level in male mice.

\begin{tabular}{lcccccc}
\hline AM & \multicolumn{5}{c}{ Treatment Groups $($ mean \pm SD) } \\
\hline & Control & AEAM & AEAM & AEAM & AEAM & AEAM \\
& & 50 & 100 & 200 & 500 & 1000 \\
\cline { 2 - 6 } & & & & & \\
$\begin{array}{l}\text { Testosterone } \\
\begin{array}{l}\text { concentration } \\
(\mathrm{ng} / \mathrm{ml})\end{array}\end{array}$ & $3.08 \pm 1.15$ & $3.07 \pm 2.06$ & $2.91 \pm 1.00$ & $3.12 \pm 0.96$ & $2.41 \pm 1.28$ & $2.16 \pm 0.89$ \\
\hline * The mean difference is significant at $\mathrm{p}<0.05$ level $(\mathrm{n}=5$ in each group) &
\end{tabular}

Contrary result was obtained from the present study because there was no significant changes recorded in testosterone concentration at all doses administered when compared with control (Figure 2). Clinical information on testosterone likewise proposes that a slight increment in the levels of the hormone in adult males results in a moderate but significant increase in sexual desire and libido [45, 36]. Surprisingly, in the present study the slight increment in testosterone level in AEAM 200 was not associated with the changes in sexual behaviour and orientation activity (towards self and towards females) because the scoring for these parameters were remained similar with the other treated groups. Thus, the sedative effect was found to be the main factor to reduce the score recorded in sexual behaviour and orientation activity (towards self and towards females) in experimental animals.

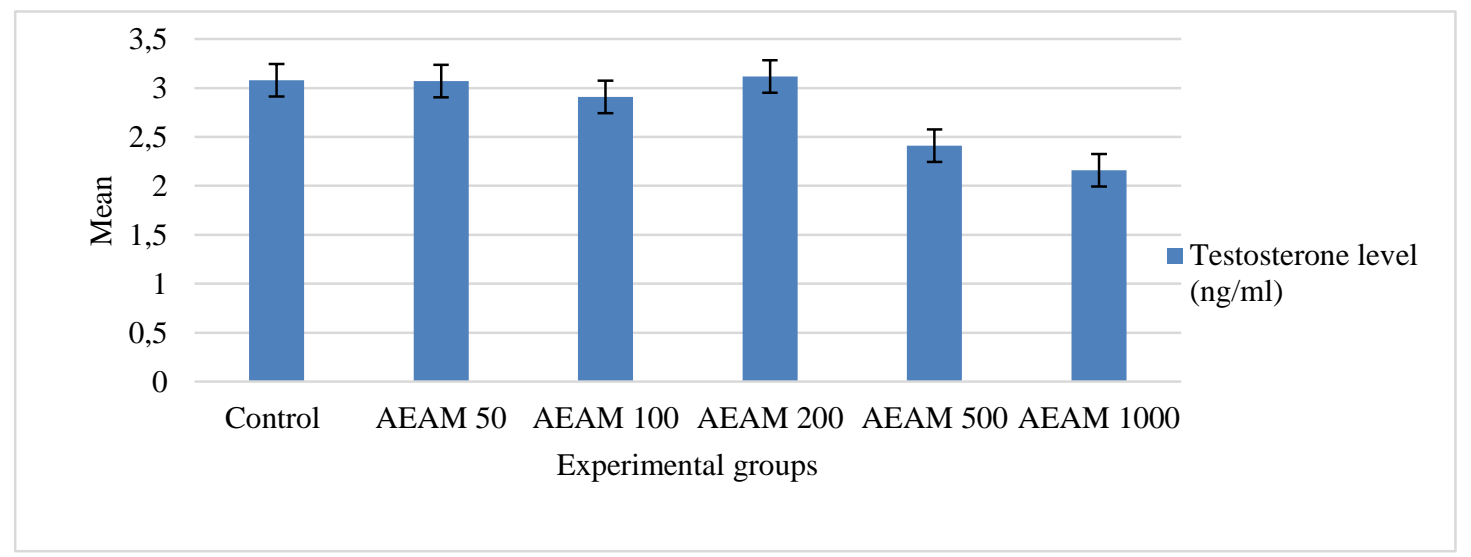

Figure 2. Various doses effect of $A$. malaccensis aqueous leaves extract in testosterone level estimation towards mice

\section{CONCLUSION}

The results of the present study show that the treated male mice with an aqueous extract of $A$. malaccensis leaves (AEAM) in the presence of non-oestrous female did not increase their sexual performance for two hours observation period at day $0,7,14$ and 21. The prolong treatment with AEAM caused inconsistently decrease in sexual behaviour and orientation activity (towards female and towards self) parameters that recorded in treated animals especially in AEAM 1000. This study has thus discovered that the aqueous leaves extract of $A$. malaccensis possess lack of aphrodisiac properties towards mice.

\section{MATERIALS AND METHODS}

All methods that applied in this study was done under proper research ethics and care that was approved by Universiti Pendidikan Sultan Idris research committee.

\subsection{Plant sample extraction}

The fresh leaves of $A$. malaccensis were collected from Agarwood Al-Hilmi plantation in Behrang, Perak, Malaysia. The plant specimen was collected in November 2015, identified and deposited at the Herbarium of Universiti Pendidikan Sultan Idris. The plant specimen was assigned a voucher numbers NHCM001. In plant sample extraction the leaves were washed, air dried, and ground using electrical grinder to form the fine powder. $800 \mathrm{~g}$ of the powder were macerated in $8 \mathrm{~L}$ of distilled water for $24 \mathrm{~h}$ at room temperature with occasional stirring. The mixtures were filtered using cloth filter at room temperature [46] and the filtrate obtained were oven dried at $55^{\circ} \mathrm{C}$ for 48 hours [47], followed by freeze drying for $72 \mathrm{~h}$ [48]. The brown crude extract obtained was stored at $-20^{\circ} \mathrm{C}$ prior to further use. 


\subsection{Experimental design}

Repeated oral dose administration was carried out in this experiment. In this test, 30 adult male mice were used. 30 male mice were divided into 6 groups of 5 mice each group and treated with crude extract using plastic syringes attached to ball-tipped stainless steel feeding needle daily for 21 days consecutively as the following in Table 1. The administration volume was $10 \mathrm{~mL} / \mathrm{kg}$ b.w of the animal [49]. The amount of crude extract was calculated based on the body weight of the animal and dissolved in distilled water before administered directly to the mice [50]. Before the administration of crude extract, the animals were fasted overnight. During the experiment period, food and water were given ad libitum.

Table 1. The different doses of $A$. malaccensis aqueous leaves extract (AEAM)

\begin{tabular}{ll}
\hline Group & Treatment \\
\hline Control & Mice received $10 \mathrm{ml} / \mathrm{kg}$ body weight of normal saline $(\mathrm{n}=5)$ \\
AEAM 50 & Mice received $50 \mathrm{mg} / \mathrm{kg}$ body weight $/$ day crude extract $(\mathrm{n}=5)$ \\
AEAM 100 & Mice received $100 \mathrm{mg} / \mathrm{kg}$ body weight $/$ day crude extract $(\mathrm{n}=5)$ \\
AEAM 200 & Mice received $200 \mathrm{mg} / \mathrm{kg}$ body weight $/$ day crude extract $(\mathrm{n}=5)$ \\
AEAM 500 & Mice received $500 \mathrm{mg} / \mathrm{kg}$ body weight $/$ day crude extract $(\mathrm{n}=5)$ \\
AEAM 1000 & Mice received $1000 \mathrm{mg} / \mathrm{kg}$ body weight $/$ day crude extract $(\mathrm{n}=5)$ \\
\hline
\end{tabular}

\subsection{Parameter in assessing plant with aphrodisiac activity}

\subsubsection{Sexual behaviour test}

Healthy and sexually experienced male albino mice that showing brisk sexual activity were selected for the study. The methods that implemented in this study was approved by Universiti Pendidikan Sultan Idris research ethics committee. The experimental animals were divided into six groups of five animals each and kept singly in separate polysulfone cages during the experiment as mention in the experimental design above. First group represents the control group, which received $10 \mathrm{ml} / \mathrm{kg}$ of normal saline orally. The other five groups were received suspension of five different doses of water extract of A. malaccensis at the doses of 50,100, 200,500 and $1000 \mathrm{mg} / \mathrm{kg}$ body weight respectively. All oral administrations were done daily at the same point time of between 08:00 am and 09:30 am for 21 days. The observation was done on 0, 7, 14 and 21 days after orally treated with different doses of agarwood aqueous extract. The experiment was conducted at 09:00 a.m until 2:00 p.m in the same laboratory and under the light of the same intensity. The non-estrous female mice were introduced into the polysulfone cages of male animals with 1 female to 1 male ratio. During observation period, any jerking movement of the mating area was avoided to enable the mice to chase each other; and cleaning of the mating area was performed after each trial, since the urine trails left by one mouse might alter the sexual behavior of the next mouse [51]. The occurrence of events and phases of mating were recorded using CCTV video camera about 2 hours [52].

The behavioural observations were carried out by taking into account the following parameters that described by [53] and [54].

Mounting Behaviour - It was determined and characterized by following parameters.

(A) Mount frequency - The average number of mount by a male mice without intromission during 2 hours observation

(B) Mount latency- The lag time in minutes from the introduction of female in the cage to first mount.

Intromission Behaviour - It was evaluated according to these following aspects.

(A) Intromission frequency - The average number of Intromission during 2 hours observation

(B) Intromission latency- The time in minutes for first intromission after introduction of female in the cage. 


\subsubsection{Orientation activity test}

The same mice in sexual behaviour were used in this test. The test was done in 30 minutes early of the sexual behaviour observation method [55]. The orientation activity was carried out about three weeks of treatment and analyzed in three segments [56,57].

Orientation behaviour of male mice were determined using following method of scoring:

Orientation towards female - ( 1 for every sniffing and 2 for every licking)

Orientation towards self - ( 1 for non-genital grooming and 2 for genital grooming)

Orientation towards environment - ( 1 for exploration, 2 for rearing and 3 for climbing)

The cumulative score at $0,7,14$ and 21 days of the treatment of experimentation were recorded using CCTV video camera.

\subsubsection{Testosterone estimation}

After 21 days of treatment with plant extract, blood samples were drawn from the mice' hearts by cardiac puncture method. Blood samples were collected in test tubes while the mice are put under mild ether anesthesia in the morning of day 22. Test tubes that contain blood samples were gathered and left at room temperature for 1 hour. After coagulation, the tubes were placed into the centrifuge at $3000 \mathrm{rpm}$ for $15 \mathrm{~min}$ to collect the plasma prior to testosterone determination [58]. Sera was pipetted by micro pipettes and transferred into new, label tubes, sealed with parafilm and stored to freeze overnight at $-20^{\circ} \mathrm{C}$ before being used in measurement of testosterone using ELISA.

\subsubsection{Blood collection method}

In general, blood withdrawal by cardiac puncture is considered terminal procedures of the study to collect a single, good quality and large volume of blood and must be performed only after ensuring that the animal is under surgical anesthesia [59]. Blood collection method was described by [60]. In this procedure 1 $\mathrm{ml}$ syringe and a 20 gauge $\times 1.5^{\prime \prime}$ needle were used. The procedure starts by palpating heart of the mice and inserting $5 \mathrm{~mm}$ needle from the center of the thorax towards the animal's chin, 5-10 mm deep and the syringe was held 25-30 degrees away from the chest. The needle was withdrawn after sufficient amount of blood able to be collected and blood was transferred into the test tube. Lastly, the secondary method of euthanasia was performed to ensure that the animal is deceased.

\subsubsection{ELISA method}

Serum testosterone concentration of the experimental animals was assayed using the procedure outlined in the manufacturer's instruction manual (Testosterone ELISA Kit ab108666).

\subsection{Statistical analysis}

The results were expressed as mean $\pm \mathrm{SD}$. Statistical analyses were performed using one-way ANOVA and followed by Tukey's test for parametric multiple comparisons between the control and the treatment groups. The values were considered significantly different when the $p$ value was less than $0.05(p<0.05)$.

Acknowledgements: The authors are thankful to the Al-Hilmi Group of Companies for awarding research grant, 20150170-102-29 for the financial support and also the Biology Department, Faculty of Science and Mathematics, University Pendidikan Sultan Idris and Malaysia Genome Institute for providing facilities to conduct this research.

Author contributions: Concept - N. H. C. M., H. H. M. Z., H. I.; Design - N. H. C. M., H. H. M. Z., H. I.; Supervision N. H. C. M., H. H. M. Z., H. I.; Resource - N. H. C. M., H. H. M. Z., H. I.; Materials - N. H. C. M., H. H. M. Z., H. I.; Data Collection and/or Processing N. H. C. M., H. H. M. Z., H. I.; Analysis and/or Interpretation - N. H. C. M., H. H. M. Z., H. I.; Literature Search - N. H. C. M., H. H. M. Z., H. I.; Writing - N. H. C. M., H. H. M. Z., H. I.; Critical Reviews - N. H. C. M., H. H. M. Z., H. I.

Conflict of interest statement: The authors declared no conflict of interest.

\section{REFERENCES}

[1] Yakubu MT, Afolayan AJ. Effect of aqueous extract of Bulbine natalensis (Baker) stem on the sexual behaviour of male rats. Int J Androl. 2009; 32(6): 629-636. [CrossRef]

[2] Patel DK, Kumar R, Prasad SK, Hemalatha S. Pharmacologically screened aphrodisiac plant-A review of current scientific literature. Asian Pac J Trop Biomed. 2011; 1(1): S131-S138. [CrossRef] 
[3] Yakubu MT, Akanji MA, Oladiji AT. Aphrodisiac potentials of the aqueous extract of Fadogia agrestis (Schweinf. Ex Hiern) stem in male albino rats. Asian J Androl. 2005; 7(4): 399-404. [CrossRef]

[4] Kanyanga C, Wembonyama L, Muganza M, Maya M, Kabangu K. Effects of the lyophilized aqueous extract form the root bark of Perianthus Longifolia Miers (Menispermaceae ) on sexual behaviors of normal male wistar rats and its acute toxicity. World J Pharm Pharm Sci. 2016; 5(4): 135-155. [CrossRef]

[5] Sharma P, Bhardwaj P, Arif T, Khan I, Singh R. Pharmacology, phytochemistry and safety of aphrodisiac medicinal plants: A review. J Pharmaco Toxico Stud. 2014; 2(3): 1-18.

[6] Mathur M. Herbal aphrodisiac their need, biology and status: Global and regional scenario. J Nat Prod. 2012; 5: 131146.

[7] Kotta S, Shahid AH, Javed A. Exploring scientifically proven herbal aphrodisiacs. Pharmacogn Rev 2013; 7(13): 1 10.

[8] Norhazlina AW, Norfilza MM, Wan Nurul Heriza AH, Das S. The effect of Eurycoma longifolia Jack on spermatogenesis in estrogentreated rats. Clinics. 2010; 65(1):93-98.

[9] Amal Salem FM, Mahanem MN. Comparative study on the effect of Eurycoma longifolia and Smilax myosotiflora on male rats fertility. AIP Conference Proceedings. 2013; 1571:227-233. [CrossRef]

[10] Nurdiana S, Zanariah A, Mohd Luqman Hakim MN, Mohd Idzham, Abu Zarin. Effect of Ficus deltoidea leaves extracts on sperm quality, LDH-C 4 activity and testosterone level in alloxan-induced male diabetic rats. IEEE Colloquium on Humanities, Science and Engineering. 2011.

[11] Saheera K, Munirah S, Suzanah AR. Effects on mouse spermatogenesis and DNA fragmentation following exposure to cyclophosphamide and thymoquinone. Eur Int J Sci Technol. 2013; 2(7):119-136.

[12] Nor-Raidah R, Mahanem MN. Enhancement of fertility and libido in male Sprague Dawley rats following the administration of aqueous extract of Lunasia amara. Malays Appl Biol. 2015; 44(1):125-131.

[13] Pusparanee H, Halimah AS, Mahanem MN. Effects of Gynura procumbens extract and glibenclamide on sperm quality and specific activity of testicular lactate dehydrogenase in Streptozotocin-induced diabetic rats. Malaysian J Biochem Mol Biol. 2008; 16(2):10-14.

[14] Giribabu N, Kumar KE, Rekha SS, Muniandy S, Salleh N. Chlorophytum borivilianum (Safed Musli) root extract prevents impairment in characteristics and elevation of oxidative stress in sperm of Streptozotocin-induced adult male diabetic Wistar rats. BMC Complement Altern Med. 2014; 14(1):291.

[15] Ismail M, Mohd Zin J, Gaharu: Komoditi Khazanah. Selangor: Universiti Putra Malaysia, Malaysia, 2011.

[16] Fatmawati, Hidayat R. Anti-cancer activity of Aquilaria malaccensis leaves on human. Eur J Pharm Med Res. 2016;3(1): 46-49.

[17] Bahrani H, Mohamad J, Paydar MJ, Rothan HA. Isolation and characterisation of acetylcholinesterase inhibitors from Aquilaria subintegra for the treatment of Alzheimer's disease (AD). Curr Alzheimer Res. 2014; 11(2): 206-214. [CrossRef]

[18] Kakino M, Tazawa S, Maruyama H, Tsuruma K, Araki Y, Shimazawa M, Hara H. Laxative effects of agarwood on low-fiber diet-induced constipation in rats. BMC Complement Altern Med. 2010; 10(1): 68. [CrossRef]

[19] Hara H, Ise Y, Morimoto N, Shimazawa M, Ichihashi K, Ohyama M, Iinuma M. Laxative effect of agarwood leaves and its mechanism. Biosci Biotechnol Biochem. 2008; 72(2): 335-345. [CrossRef]

[20] Zhou M, Wang H, Kou J, Yu B. Antinociceptive and anti-inflammatory activities of Aquilaria sinensis (Lour.) Gilg. leaves extract. J Ethnopharmacol. 2008; 117(2): 345-350. [CrossRef]

[21] Dash M, Patra JK, Panda PP. Phytochemical and antimicrobial screening of extracts of Aquilaria agallocha Roxb. Afr J Biotechnol. 2008; 7: 3531-3534.

[22] Begum Y. Study on agarwood (Aquilaria malaccensis) to evaluate antibacterial and antioxidant activities of n-hexane, chloroform and ethyl acetate extracts. Pharma Tutor. 2016; 4(2): 47-50.

[23] Pranakhon R, Pannangpetch P, Aromdee C. Antihyperglycemic activity of agarwood leaf extracts in STZ-induced diabetic rats and glucose uptake enhancement activity in rat adipocytes. J Sci Technol. 2011; 33(4): 405-410.

[24] Chen D, Bi D, Song YL, Tu PF. Flavanoids from the stems of Aquilaria sinensis. Chin J Nat Med. 2012; 10 (4): $287-291$. [CrossRef]

[25] Yang L, Qiao L, Xie D, Yuan Y, Chen N, Dai J, Guo S. 2-(2-Phenylethyl) chromones from Chinese eaglewood. Phytochem. 2012; 76: 92-97. [CrossRef] 
[26] Peng K, Mei WL, Zhao YX, Tan LH, Wang QH, Dai HF. A novel degraded sesquiterpene from the fresh stem of Aquilaria sinensis. J Asian Nat Prod Res. 2011; 13(10): 951-955. [CrossRef]

[27] Chen HQ, Wei JH, Yang JS, Zhang Z, Yang Y, Gao ZH, Gong B. Chemical constituents of agarwood originating from the endemic genus Aquilaria plants. Chem Biodivers. 2012; 9(2): 236-250. [CrossRef]

[28] Khalil AS, Rahim AA, Taha KK, Abdallah KB. Characterization of methanolic extracts of agarwood leaves. J Appl Indus Sci. 2013; 1(3): 78-88.

[29] Naef R. The volatile and semi-volatile constituents of agarwood, the infected heartwood of Aquilaria species: a review. Flavour Fragr J. 2011; 26(2): 73-87. [CrossRef]

[30] Chetpattananondh P. Overview of the agarwood oil industry. Proceeding of the IFEAT International Conference (pp. 131-138). 2012; Singapura.

[31] Alam J, Mujahid M, Rahman M, Akhtar J, Khalid M, Jahan Y, Basit A, Khan A, Shawwal M, Iqbal SS. An insight of pharmacognostic study and phytopharmacology of Aquilaria agallocha. J Appl Pharm Sci. 2015; 5(8): 173-181. [CrossRef]

[32] Gauthaman K, Ganesan AP, Prasad RNV. Sexual effects of puncturevine (Tribulus terrestris) extract (protodioscin): an evaluation using a rat model. J Altern Complement Med. 2003; 9(2): 257-265. [CrossRef]

[33] Zamblé A, Martin-Nizard F, Sahpaz S, Reynaert ML, Staels B, Bordet R, Bailleul F. Effects of Microdesmis keayana alkaloids on vascular parameters of erectile dysfunction. Phytother Res. 2009; 23(6): 892-895. [CrossRef]

[34] Yakubu MT, Akanji MA. Effect of aqueous extract of Massularia acuminata stem on sexual behaviour of male wistar rats. Evid Based Complement Alternat Med. 2011. [CrossRef]

[35] Silva CV, Borges FM, Velozo ES. Phytochemistry of some Brazilian plants with aphrodisiac activity. In: Phytochemicals. 2012. [CrossRef]

[36] Dasofunjo K, Asuk AA, Ezugwu HC, Nwodo OFC, Olatunji TL. Aphrodisiac effect of ethanol extract of Piliostigma thonningii leaf on male albino wistar rats. J Appl Pharm Sci. 2013; 3(10): 130-135. [CrossRef]

[37] Wawata AU, Dikko AAU, Olorunshola KV, Wawata MU, Attahir A, Ahmed MK. The effect of aqueous methanolic stem bark extracts of Acacia polyacantha on sexual behaviour, serum testosterone levels in male wistar rats. Asian J Med Sci. 2010; 2(3): 138-140.

[38] Nchegang B, Mezui C, Longo F, Nkwengoua Z E, Amang A P, Tan PV. Effects of the aqueous extract of Eremomastax speciosa (Acanthaceae) on sexual behavior in normal male rats. Biomed Res Int. 2016; Article ID 9706429. [CrossRef]

[39] Fouche G, Afolayan AJ, Wintola OA, Khorombi TE, Senabe J. Effect of the aqueous extract of the aerial parts of Monsonia angustifolia E. Mey. Ex A. Rich., on the sexual behaviour of male Wistar rats. BMC Complement Altern Med. 2015; 15(1): 343. [CrossRef]

[40] Yakubu MT, Awotunde OS, Ajiboye TO, Oladiji AT, Akanji MA. Pro-sexual effects of aqueous extracts of Massularia acuminata root in male Wistar rats. Andrologia. 2011; 43(5): 334-340. [CrossRef]

[41] Yakubu MT, Quadri AL. Garcinia kola seeds: Is the aqueous extract a true aphrodisiac in male Wistar rats? Afr J Tradit Complement Altern Med. 2012; 9(4): 530-535.

[42] Balamurugan G, Muralidharan P, Polapala S. Aphrodisiac activity and curative effects of Pedalium murex (L.) against ethanol-induced infertility in male rats. Turk J Biol. 2010; 34: 153-163.

[43] Patel DK, Kumar R, Laloo D, Sairam K, Hemalatha S. Aphrodisiac activity of ethanolic extract of Pedalium murex Linn fruit. Asian Pac J Trop Biomed. 2012; 2(3): S1568-S1571. [CrossRef]

[44] Chauhan NS, Saraf DK, Dixit VK. Effect of vajikaran rasayana herbs on pituitary-gonadal axis. Eur J Integr Med. 2010; 2(2), 89-91. [CrossRef]

[45] Thakur M, Dixit VK. Aphrodisiac activity of Dactylorhiza hatagirea (D. Don) Soo in male albino rats. Evid Based Complement Alternat Med. 2007; 4(S1): 29-31.

[46] Kazmi I, Afzal M, Rahman M, Gupta G, Anwar F. Aphrodisiac properties of Polygonatum verticillatum leaf extract. Asian Pac J Trop Dis. 2012; 2: S841-S845. [CrossRef]

[47] Carro-Juarez M, Franco MA, Rodriguez-Pena MDL. Increase of the ejaculatory potency by the systemic administration of aqueous crude extracts of cihuapatli (Montanoa genus) plants in spinal male rats. J Evid Based Complement Altern Med. 2014; 19(1): 43-50. [CrossRef] 
[48] Nik Noor Asma NW, Nor Adila MO, Noorhuda AI, Saiful Nizam T. In vitro antioxidant activity and phytochemical screening of Aquilaria malaccensis leaf extracts. J Chem Pharm Res. 2014; 6(12): 688-693.

[49] Ghan SY, Chin JH, Thoo YY, Yim HS, Ho CW. Acute oral toxicity study of Aquilaria crassna and a-Tocopherol in mice. Int J Pharm Sci Res. 2016; 7(4): 1456.

[50] Mounira M. Evaluation of toxicity in mice and rats and antioxydant activities of Ruta montana L. extracts. University Ferhat Abbas Setif 1. 2015. www.univ-setif.dz/Tdoctorat/2015/SNV/MERGHEM MOUNIRA.pdf

[51] Zade V, Dabhadkar D, Thakare V, Pare S. Evaluation of potential aphrodisiac activity of Moringa oleifera seed in male albino rats. Int J Pharm Pharm Sci. 2013; 5(Suppl 4): 683-689.

[52] Guohua H, Yanhua L, Rengang M, Dongzhi W, Zhengzhi M, Hua Z. Aphrodisiac properties of Allium tuberosum seeds extract. J Ethnopharmacol. 2009; 122(3): 579-582. [CrossRef]

[53] Mokhtari M, Zanboori M. the effects of lead acetate on sexual behavior and the level of testosterone in adult male rats. Int J Fertil Steril. 2011; 5(1): 13-20.

[54] Palaniyappan V, Kothandam H, Vasu S, Moses P, Sundaram S. Evaluation of phytoconstituents and aphrodisiac activity of the fruits of Durio zibenthinus Linn. J Pharm Res. 2009; 2(9): 1493-1495.

[55] Jamshidzadeh A, Sajedianfard J, Nekooeian AA, Tavakoli F, Omrani GH. Effects of camphor on sexual behaviors in male rats. Iran J Pharm Sci. 2006; 2(4): 209-214.

[56] Islam MW, Tariq M, Ageel AM, Al-Said MS, Al-Yhya AM. Effect of Salvia hematodes on sexual behaviour of male rats. J Ethnopharmacol. 1991; 33: 67- 72. [CrossRef]

[57] Pare SR, Zade VS, Thakare VG. Evaluation of the potential aphrodisiac activity of aqueous, chloroform and alcohol extract of Gloriosa superba in male albino rat. Int J Theor Appl Sci. 2014; 6(2): 39.

[58] Low BS, Das PK, Chan KL. Standardized quassinoid-rich Eurycoma longifolia extract improved spermatogenesis and fertility in male rats via the hypothalamic-pituitary- gonadal axis. J Ethnopharmacol. 2013; 145(3): 706-714. [CrossRef]

[59] Parasuraman S, Raveendran R, Kesavan R. Blood sample collection in small laboratory animals. J Pharmacol Pharmacother 2010; 1(2): 87-93. [CrossRef]

[60] Hoff J. Methods of blood collection in the mouse. Lab Animal 2000; 29(10): 47-53. http://www.lawte.org/materials/hoff.pdf (accessed March 18, 2016). 